\title{
Self-Regulated Learing Siswa Kelas XI IPS Pada Mata Pelajaran Ekonomi di SMA Negeri 3 Singaraja
}

\author{
Ni Kadek Andewi Restila Sari ${ }^{\star 1}$, Luh Indrayani² \\ 1,2Program Studi Pendidikan Ekonomi \\ Universitas Pendidikan Ganesha \\ Singaraja, Indonesia
}

e-mail: nikadekandewirestilasari04@undiksha.ac.id*1, luh indrayani@undiksha.ac.id²

Pengutipan: Sari, N. K. A. R. \& Indrayani, L. (2021). SelfRegulated Learning Siswa Kelas XI IPS

Pada Mata

Pelajaran

Ekonomi di SMA

Negeri 3

Singaraja. Jurnal

Pendidikan

Ekonomi

Undiksha, 13 (2),

319-327

http://dx.doi.org/1 0.23887/ijpe.v13i $\underline{2.34930}$

\begin{abstract}
Abstrak
Riwayat Artikel Tanggal diajukan: 1 Juni 2021

Tanggal diterima : 22 November 2021

Tanggal dipublikasikan: 15 Desember 2021

Penelitian ini bertujuan untuk mengetahui self-regulated learning siswa kelas XI IPS pada Mata Pelajaran Ekonomi di SMA Negeri 3 Sigaraja yang ditinjau dari dimensi motif, metode, waktu, perilaku, lingkungan fisik dan lingkungan sosial. Jenis penelitian ini adalah deskriptif dengan pendekatan kualitatif. Populasi penelitian yakni seluruh siswa kelas XI IPS di SMA Negeri 3 Singaraja dengan jumlah 103 orang siswa. Teknik sampling yang digunakan yakni sampling jenuh, dimana teknik ini menggunakan seluruh populasi. Data penelitian diperoleh melalui penyebaran kuesioner dan dokumentasi yang selanjutnya dianalisis dengan mendeskripsikan data yang telah diperoleh. Hasil penelitian menunjukkan bahwa self-regulated learning siswa kelas XI IPS pada Mata Pelajaran Ekonomi di SMA Negeri 3 Singaraja ditinjau dari dimensi motif, metode, perilaku, lingkungan fisik berada pada kategori baik, sedangkan ditinjau dari dimensi waktu dan lingkungan sosial berada pada kategori kurang baik.
\end{abstract}

Kata kunci: Self-Regulated Learning; Motif; Metode; Waktu; Perilaku

\begin{abstract}
The purpose of this study is to find the students' self-regulated Learning of class XI IPS on Economics subjects at SMA Negeri 3 Singaraja in terms of the dimensions of motives, methods, time, behavior, physical environment and social environment. The type of the research was descriptive study with qualitative approach. The populations were all class of XI IPS at SMA Negeri 3 Singaraja with a total of 103 students. Saturated sampling used in this study, this sampling technique uses the entire study population. The data collection methods used were questionnaires and documentation. The data analysis technique used was descriptive analysis. The results showed that the students' self-regulated learning of class XI IPS on Economics Subjects at SMA Negeri 3 Singaraja in terms of the dimensions of motives, methods, behavior, physical environment were in a good category, while in terms of time dimensions and social environment were in the category of less well.
\end{abstract}

Keywords : Self-Regulated Learning; Motive; Methods, Time; Behavior 


\section{PENDAHULUAN}

Secara umum pendidikan diperoleh baik secara formal maupun informal. Pelaksanaan pendidikan formal dilaksanakan di sekolah baik negeri maupun swasta. Menurut Winoto (2020) pendidikan dalam perspektif pendidikan formal diartikan sebagai suatu proses dan usaha untuk meningkatkan potensi peserta didik baik akademik, emosi dan spiritual agar dapat berkembang secara maksimal yang dilakukan secara sadar.

Di sekolah siswa mempelajari berbagai mata pelajaran yang harus mereka tempuh. Sehingga, dalam mengoptimalkan proses pembelajaran pada berbagai mata pelajaran, siswa harus mampu mengatur diri dalam belajar agar setiap mata pelajaran yang ditempuh membuahkan hasil yang baik. Pentingnya melakukan pengaturan diri bagi siswa dalam kegiatan belajar yakni, agar dalam mengerjakan tugas-tugasnya seperti pekerjaan rumah (PR), siswa terbiasa mengatur waktu belajar, memotivasi diri, membuat perencanaan belajar agar dapat belajar dengan optimal.

Kemampuan siswa dalam mengatur diri dalam belajar disebut sel-regulated learning. Menurut Jacob et al,. (2020) selfregulated learning penting untuk karier sekolah seseorang dan keberhasilan akademis mereka dikemudian hari, oleh karena itu harus dipupuk sedini mungkin.

Self-regulated learning diartikan sebagai proses aktif dan konstruktif siswa dalam mengatur belajarnya atas inisiatifnya sendiri dengan menggunakan pikiran, perasaan dan perilaku untuk mencapai tujuan belajar (Hidayah \& Atmoko, 2014). Menurut Sutikno (2016) self-regulated learning merupakan proses belajar mengatur diri berupa gagasan, mengubah kebiasaan, perhatian dan tindakan yang dilakukan dalam mempertahankan dan meningkatkan hasil belajar.

Tugas belajar siswa umumnya sangat kompleks, dimana siswa disibukkan oleh tugas dari beragam mata pelajaran. Pengerjaan tugas belajar tentunya membutuhkan konsentrasi yang bagus, fasilitas yang memadai, motivasi dalam diri dan memiliki keyakinan mampu menyelesaikan tugas, serta siswa harus bisa mengelola sumber belajar dan memilih rekan belajar. Hal ini menunjukkan pentingnya siswa mampu mengatur diri dalam belajarnya.

Menurut Sucipto (2014) menyatakan bahwa hasil belajar ekonomi peserta didik pada mata pelajaran ekonomi dipengaruhi oleh self-regulated learning. Sejalan dengan pernyataan tersebut, Rahmiyati (2017) menyatakan bahwa self-regulated learning memiliki peran penting untuk meningkatkan prestasi belajar siswa. Selanjuntya, Puspita \& Rustika (2018) mengungkapkan bahwa remaja yang mempunyai self-regulated learning yang baik, dalam mencapai prestasi yang diharapkan memiliki motivasi tersendiri. Pendapat selanjutnya dikemukakan oleh Yulanda (2017) bahwa self-regulated learning berperan memberikan dorongan dalam kegiatan individu seperti mengelola pembelajaran sendiri, serta sebagai strategi belajar.

Dalam membuat sebuah strategi terdapat fase-fase yang harus dilalui, menurut Kurnia \& Warmi (2020) terdapat tiga fase self-regulated learning yaitu, pertama perencanaan pada tahap ini merupakan penentuan startegi belajar yang akan digunakan. Kedua, pelaksanaan merupakan tahap penerapan strategi kognitif dan metakognitif. Ketiga, evaluasi merupakan tahapan pemilihan strategi untuk mengatasi kegagalan dalam belajar. Menurut Koro et al., (2017) menyatakan bahwa strategi self-regulated learning terdiri atas dua yaitu strategi kognitif yang befokus pada pemerolehan informasi, elaboration dan organisasi. Strategi metakognitif berkaitan dengan kemampuan berfiki serta perilaku siswa selama proses belajar.

Berdasarkan pemaparan di atas, selfregulated learning memiliki peran penting dalam kegiatan belajar siswa. Siswa yang mampu mengatur dirinya dalam belajar akan meminimumkan kegagalan dalam proses belajarnya. Dikalangan SMA banyak terdapat siswa yang belum bisa mengatur diri dalam belajarnya, siswa masih kesulitan dalam memenuhi tugas atau kewajiban belajarnya. Kurangnya self-regulated learning yang dimiliki siswa berdampak buruk pada kegiatan belajar dan prestasi akademiknya. 
Di lapangan banyak terdapat fenomena kurangnya self-regulated learning dikalangan siswa. Ketika melaksanakan PPL-Real, perilaku yang mencerminkan kurangnnya self-regulated learning siswa seperti, mengumpulkan tugas tidak tepat waktu, mencontek pekerjaan teman sejawatnya, tidak serius dalam mengerjakan tugas, kurangnya partisipasi selama kegiatan belajar. Beberapa hasil penelitian terdahulu juga menunjukkan penerapan self-regulated learning masih rendah dikalangan siswa. Berdasarkan hasil penelitian Febriyanti \& Imami (2021) menyatakan bahwa self-regulated learning siswa masih sangat rendah pada pelajaran matematika. Selanjutnya, Yeni et al., (2021) menyatakan bahwa self-regulated learning berada pada tingkat cukup pada siswa di kelas Bahasa Inggris. Dilihat dari hasil penelitian tersebut rendahnya self-regulated learning akan berdampak negatif terhadap pembelajaran.

Dalam penelitian ini rendahnya selfregulated learning ditemukan pada siswa kelas XI IPS di SMA Negeri 3 Singaraja saat peneliti melaksanakna PPL-Real. Hasil dari observasi yang dilakukan pada siswa tersebut, mereka mengungkapkan belum membuat perencanaan dalam belajarnya, belum mengatur waktu belajar secara khusus, minimnya interaksi dengan lingkungan sekitar, sehingga mereka cenderung kesulitan dalam menyelesaikan tugas belajar. Sehingga dapat disimpulkan, rendahnya self-regulated learning digambarkan dengan kurangnya kemampuan siswa dalam mengatur waktu, malas dalam mencari sumber belajar dan siswa lebih memilih mencontek daripada berdiskusi dengan teman atau mitra belajar mengenai materi pembelajaran.

Dari uraian tersebut terdapat beberapa dimensi self-regulated learning. Dimensi ini penting secara teoritis dan empiris,menurut Zimmerman (2013) menyatakan bahwa diemensi self-egulated learning terdiri atas enam yaitu pertama motif dimana melibatkan adanya keyakinan akan kemampuan yang dimiliki siswa dan adanya penetapan tujuan yang ingin dicapai. Kedua, metode merupakan adanya strategi belajar yang dibuat oleh siswa dan menjadi rutinitas dalam belajarnya. Ketiga, waktu dimana siswa memiliki kemampuan dalam mengatur, mengelola waktu yang ia miliki. Keempat, perilaku menerangkan adanya pemantauan, penilaian dan reaksi diri siswaterhadap kinerja belajarnya. Kelima, lingkungan fisik merupakan lingkungan yang menunjang kegiatan belajar siswa, berupa ruangan maupun sara dan prasarana. Keenam, lingkungan sosial merupakan orang disekitas siswa baik orang tua maupun teman sebaya, dimana tempat siswa mencari bantuan dalam menyelesaikan masalah yang dihadapi dalam konteks belajar.

Berdasarkan fenomena self-regulated learning yang telah dipaparkan, peneliti tertarik untuk melakukan penelitian tentang "Self-Regulated Learning Siswa Kelas XI IPS Pada Mata Pelajaran Ekonomi di SMA Negeri 3 Singaraja" Adapun tujuan dari penelitian ini untuk mengetahui selfregulated learning siswa kelas XI IPS pada Mata Pelajaran Ekonomi di SMA Negeri 3 Singaraja yang ditinjau dari berbagai dimensi tersebut.

\section{METODE}

Jenis penelitian ini yaitu penelitian deskriptif dengan pendekatan kualitatif. Lokasi penelitian, bertempat di SMA Negeri 3 Singaraja dengan populasi penelitian adalah seluruh siswa kelas XI IPS yang berjumlah 103 orang siswa. Anggota subjek dalam populasi yang meliputi 100-150 orang dan dengan pengumpulan data peneliti menggunakan angket atau kuesioner, maka sebaiknya diambil seluruhnya Arikunto (2005). Sehingga, teknik sampling yang digunakan pada penelitian ini adalah teknik sampling jenuh, dimana seluruh populasi gunakan sebagai sampel.

Metode pengumpulan data pada penelitian ini adalah kuesioner dan dokumentasi. Kuesioner bertujuan untuk mengumpulkan data self-regulated learning berdasarkan dimensi-dimensinya. Sebelum digunakan dalam mencari data, kuesioner harus melewati uji validitas dan reliabilitas terlebih dahulu untuk mengetahui layak atau tidak suatu instrumen digunakan, sedangkan dokumentasi digunakan untuk memperoleh jumlah siswa kelas XI IPS pada Mata Pelajaran Ekonomi. 
Teknik analisis data yang digunakan adalah analisis deskriptif, dimana teknik ini mendeskripsikan self-regulated learning siswa kelas XI IPS pada Mata Pelajaran Ekonomi di SMA Negeri 3 Singaraja yang ditinjau dari enam dimensi.

\section{HASIL DAN PEMBAHASAN}

Berdasarkan hasil analisis data yang telah peneliti lakukan dengan menyebarkan kuesioner, adapun hasil dari dimensi motif dapat dilihat pada tabel 1 .

Tabel 1. Hasil Analisis Data Self-Regulated Learning siswa kelas XI IPS pada Mata Pelajaran Ekonomi di SMA Negeri 3 Singaraja ditinjau dari Dimensi Motif

\begin{tabular}{lccc}
\hline Dimensi & Skor & Rentang Skor & Kategori \\
\hline Motif & 2.057 & $1.751-2.162$ & Baik \\
Total & $\mathbf{2 . 0 5 7}$ & $1.751-2.162$ & Baik \\
\hline
\end{tabular}

Berdasarkan hasil analisis pada tabel 1 menunjukkan self-regulated learning ditinjau dari dimensi motif memperoleh skor sebesar 2.057 yang mana berada pada rentang skor 1.751-2.162, sehingga dikategorikan baik. Hasil analisis dari dimensi metode dapat dilihat pada tabel 2.

Tabel 2. Hasil Analisis Data Self-Regulated Learning siswa kelas XI IPS pada Mata Pelajaran Ekonomi di SMA Negeri 3 Singaraja ditinjau dari Dimensi Metode

\begin{tabular}{lccc}
\hline Dimensi & Skor & Rentang Skor & Kategori \\
\hline Metode & 2.037 & $1.751-2.162$ & Baik \\
Total & $\mathbf{2 . 0 3 7}$ & $1.751-2.162$ & Baik \\
\hline
\end{tabular}

Berdasarkan hasil analisis pada tabel 2 menunjukkan bahwa self-regulated learning ditinjau dari dimensi metode memperoleh skor sebesar 2.037 yang mana berada pada rentang skor 1.751-2.162, sehingga dikategorikan baik. Selanjutnya, hasil analisis yang ditinjau dari dimensi waktu disajikan pada tabel 3 .

Tabel 3. Hasil Analisis Data Self-Regulated Learning siswa kelas XI IPS pada Mata Pelajaran Ekonomi di SMA Negeri 3 Singaraja ditinjau dari Dimensi Waktu

\begin{tabular}{lccc}
\hline Dimensi & Skor & Rentang Skor & Kategori \\
\hline Waktu & 1.028 & $804-1.050$ & Kurang Baik \\
Total & $\mathbf{1 . 0 2 8}$ & $804-1.050$ & Kurang Baik \\
\hline
\end{tabular}

Hasil analisis pada tabel 3 menunjukkan bahwa self-regulated learning ditinjau dari dimensi waktu memperoleh skor sebesar 1.028 yang mana berada pada rentang skor
804-1.050, sehingga dikategorikan kurang baik. Hasil analisis self-regulated learning yang ditinjau dari dimensi perilaku dapat dilihat pada tabel 4 .

Tabel 4. Hasil Analisis Data Self-Regulated Learning Siswa Kelas XI IPS pada Mata Pelajaran Ekonomi di SMA Negeri 3 Singaraja ditinjau dari Dimensi Perilaku

\begin{tabular}{lccc}
\hline Dimensi & Skor & Rentang Skor & Kategori \\
\hline Perilaku & 2.863 & $2.451-3.027$ & Baik \\
Total & $\mathbf{2 . 8 6 3}$ & $2.451-3.027$ & Baik \\
\hline
\end{tabular}


Berdasarkan hasil analisis pada tabel 4 maka dapat diketahui bahwa dimensi perilaku memperoleh skor sebesar 2.863 yang mana berada pada rentang skor 2.451-
3.027, sehingga dikategorikan baik. Berikutnya hasil analisis dimensi lingkungan fisik disajikan pada tabel 5 .

Tabel 5. Hasil Analisis Data Self-Regulated Learning Siswa Kelas XI IPS pada Mata Pelajaran Ekonomi di SMA Negeri 3 Singaraja ditinjau dari Dimensi Lingkungan Fisik

\begin{tabular}{lccc}
\hline Dimensi & Skor & Rentang Skor & Kategori \\
\hline Lingkungan Fisik & 1.192 & $1.051-1.297$ & Baik \\
Total & $\mathbf{1 . 1 9 2}$ & $1.051-1.297$ & Baik \\
\hline
\end{tabular}

Berdasarkan hasil analisis pada tabel 5 menunjukkan bahwa self-regulated learning ditinjau dari dimensi lingkungan fisik memperoleh skor sebesar 1.192 yang mana berada pada rentang skor 1.051-1.297, sehingga dikategorikan baik. Selanjutnya, hasil analisis dimensi lingkungan sosial dapat dilihat pada tabel 6 .

Tabel 6. Hasil Analisis Data Self-Regulated Learning Siswa Kelas XI IPS pada Mata Pelajaran Ekonomi di SMA Negeri 3 Singaraja ditinjau dari Dimensi Lingkungan Sosial

\begin{tabular}{lccc}
\hline Dimensi & Skor & Rentang Skor & Kategori \\
\hline Lingkungan Sosial & 1.734 & $1339-1750$ & Kurang Baik \\
Total & $\mathbf{1 . 7 3 4}$ & $1339-1750$ & Kurang Baik \\
\hline
\end{tabular}

Berdasarkan hasil analisis pada tabel 6 maka dapat diketahui bahwa dimensi lingkungan sosial memperoleh skor sebesar 1.734 yang mana berada pada rentang skor 1339-1750, sehingga dikategorikan kurang baik.

Berdasarkan hasil penelitian yang telah dilakukan, secara keseluruhan diperoleh hasil yang baik. Berikut ini hasil analisis self-regulated learning siswa kelas XI IPS pada Mata Pelajaran Ekonomi di SMA Negeri 3 Singaraja, bila ditinjau dari dimensi motif, metode, perilaku dan lingkungan fisik menunjukkan hasil yang baik, sedangkan ditinjau dari dimensi waktu dan lingkungan sosial menunjukkan hasil yang kurang baik.

Dimensi pertama yaitu motif, terdiri atas keyakinan individu akan kemapuannya dan tujuan belajar. Siswa memiliki keyakinan terhadap kemapuan diri yang baik dalam proses belajarnya, sehingga mereka dapat menyelesaikan tugas-tugas belajar yang diberikan. Selain itu adanya keyakinan akan kemampuan diri dalam belajar, membuat mereka yakin dapat memahami materi pada setiap mata pelajaran. Keyakinan seseorang mengenai kemampuannya dalam melakukan suatu tugas maupun pekerjaan akan mendorongnya menghadapi segala hambatan, memilih untuk mencoba menghadapi tugas hingga tercapainya hasil yang diinginkan. Siswa yang memiliki keyakinan akan kemampuan dirinya, lebih percaya diri, bersemangat saat menjumpai tugas, berusaha, serta memiliki motivasi dalam menyelesaikan tugas. Penetapan tujuan penting dalam suatu proses pembelajaran, dimana individu akan belajar lebih terarah, memiliki target yang ingin dicapai. Keyakinan diri dapat membantu siswa dalam mencapai tujuan belajar yang sebelumnya telah mereka tetapkan. Pendapat tersebut sejalan dengan Zimmerman (2013) yang mengatakan bahwa, siswa yang memiliki keyakinan diri dalam belajar (efikasi diri) dapat mencapai tujuan belajarnya. Secara keseluruhan 
p-ISSN : 2599-1418

e-ISSN : 2599-1426

ditinjau dari dimensi motif siswa memiliki self-regulated learning yang baik.

Dimensi kedua yaitu metode, yang terdiri atas indikator strategi belajar dan rutinitas belajar. Pada dimensi ini rentangan skor berada pada kategori baik, maka dapat dinyatakan siswa kelas XI IPS pada Mata Pelajaran Ekonomi memiliki self-regulated learning yang baik. Hal ini menunjukkan siswa telah mampu membuat strategi belajar yang mereka yakini efektif untuk diterapkan, sehingga dengan strategi belajar tersebut mereka dapat mencapai tujuan belajarnya. Setiap siswa memiliki strategi belajar yang berbeda-beda, seperti membuat jadwal belajar dan membagi tugas atau pekerjaan. Strategi belajar yang baik yakni strategi yang dapat mengarah pada kemajuan belajar siswa. Dalam menerapkan strategi belajar, siswa membuat jadwal belajar agar pelaksanaannya berlangsung secara teratur. Pengimplementasian yang teratur inilah akan menjadi suatu rutinitas dalam belajar. Ini sejalan dengan pendapat Zimmerman (2013) yang mengatakan bahwa siswa yang memiliki self-regulated learning memilih strategi belajar dan prosedur yang diyakini efektif, siswa menjadi lebih terampil, memilih dan mengimplementasikan metode tersebut kedalam rutinitasnya.

Dimensi ketiga yaitu waktu, dengan indikator pengaturan waktu. Pada dimensi ini menunjukkan rentangan skor pada kategori kurang baik. Sehingga, ditinjau dari dimensi ini, siswa belum memiliki selfregulated learning yang baik. Ini dikarenakan siswa belum mampu membuat perencanaan waktu dalam belajar, belum mengatur waktu dengan baik, sehingga hal ini menyebabkan tugas-tugasnya tidak terselesaikan tepat waktu. Mengatur waktu atau lebih sering disebut dengan manajemen waktu penting dilakukan seorang siswa. Siswa yang mampu mengatur waktunya secara efisien dapat memanfaatkan waktu yang dimilikinya dengan sebaik-baiknya.

Dalam konteks belajar, pengaturan waktu berupa perencanaan atau pembagian porsi waktu untuk setiap aktivitas belajar. Hal ini bertujuan agar waktu yang dimiliki
Jurnal Pendidikan Ekonomi Undiksha

Vol. 13 No.2 (2021)

mencukupi untuk setiap tugas yang harus diselesaikan. Siswa yang mampu mengelola waktunya dengan baik, dapat bekerja lebih fokus, teratur dan tepat waktu dalam menyelesaikan tugas-tugasnya. Sebaliknya, siswa yang tidak mampu mengatur waktunya, akan menunda tugas belajarnya, membuat tugas ketika deadline sudah dekat serta menimbulkan perilaku mencontek. Hal ini searah dengan hasil penelitian Mulyani (2013) menyatakan bahwa pelajar yang mampu mengelola waktu dengan baik akan bisa mengatur dan merencanakan waktu secara efektif dan efisien. Sehingga, diharapkan siswa membiasakn diri mengatur waktu sejak dini, seperti membuat perencanaan waktu, beraktivitas sesuai jadwalyang telah dibuat dan memanfaatkan waktu dengan efisien.

Dimensi ke empat yaitu perilaku, meliputi indikator observasi diri, penilaian diri dan reaksi diri. Dimensi perilaku berada pada rentangan skor dengan kategori baik, maka dapat dinyatakan bahwa siswa kelas XI IPS pada Mata Pelajaran Ekonomi memiliki self-regulated learning yang baik. Hal ini menunjukkan siswa melakukan pemantauan pada setiap perkembangan dalam belajarnya. Pemantauan dalam belajar yang dilakukan siswa kelas XI IPS pada Mata Pelajaran Ekonomi seperti meninjau penyebab kegagalan dalam mencapai tujuan belajar. Ketika siswa mengetahui perilaku yang menghambat perkembangannya, ia akan berbenah diri agar kedepannya menjadi lebih baik. Selain itu, siswa kelas XI IPS mampu menilai dirinya baik performa, maupun pemahaman terhadap materi pembelajaran khususnya pada mata pelajaran ekonomi. Siswa yang mampu menilai dirinya, dapat mengetahui apakah ia telah mencapai hasil yang maksimal.

Melalui penilaian diri, siswa dapat mengetahui kekurangan dan kelebihan yang ada dalam dirinya. Penilaian diri penting dilakukannya untuk mengetahui sejauh mana perkembangan dan hambatan yang dihadapi serta sebagai bahan pertimbangan dalam mengambil keputusan. Sebagai contoh, siswa yang memperoleh nilai ulangan harian dibawah kriteria ketuntasan 
p-ISSN : 2599-1418

e-ISSN : 2599-1426

minimum (KKM), karena hasil belajarnya tidak maksimal, sehingga ia memutuskan mengubah cara belajarnya.

Dengan pemantauan dan penilaian diri dalam proses belajar khususnya pada mata pelajaran ekonomi, siswa mampu menyesuaikan hal-hal positif yang dapat dilanjutkan dalam mendukung perkembangan dan pencapaian belajarnya, baik strategi belajar maupun cara belajar.

Sebaliknya, siswa akan mengubah cara belajar apabila dirasa kurang efektif. Hal ini juga diindikasi oleh penelitian Lestari (2014) yang menyatakan bahwa pemantauan diri (self-monitoring) merupakan komponen penting dari selfregulated learning yaitu ketika siswa secara mandiri memantau kemajuan belajar mereka.

Dimensi ke lima yaitu lingkungan fisik, dilihat dari penataan lingkungan belajar. Dimensi lingkungan fisik berada pada rentang skor dengan kategori baik, sehingga dapat dinyatakan siswa kelas XI IPS pada Mata Pelajaran Ekonomi memiliki selfregulated learning yang baik. Hal ini menunjukkan siswa telah mampu melakukan penataan terhadap lingkungan belajarnya, sehingga membuat mereka nyaman dalam belajar. Dalam proses belajar lingkungan memiliki peran penting dalam menciptakan suasana yang kondusif.

Lingkungan fisik harus nyaman dan jauh dari gangguan, ini karena lingkungan yang nyaman akan memudahkan siswa berkonsentrasi ketika sedang belajar. Salah satu faktor pendukung keberlangsungan proses pembelajaran adalah lingkungan fisik yang meliputi ruang belajar atau kelas serta sarana dan prasarana belajar. Fasilitas yang memadai akan menunjang proses belajar. Hal ini diindikasi oleh pendapat Yuliastanty \& Nazif (2019) yang mengatakan lingkungan fisik yang bermanfaat dan memenuhi syarat minimal akan mendukung meningkatnya intensitas proses pembelajaran dan mempunyai pengaruh yang positif terhadap pencapaian tujuan pembelajaran.

Dimensi ke enam yaitu lingkungan sosial, pada dimensi ini menunjukkan
Jurnal Pendidikan Ekonomi Undiksha

Vol. 13 No.2 (2021)

rentangan skor yang berada pada kategori kurang baik. Ini menunjukkan siswa belum mampu berinteraksi dengan baik pada lingkungan sosialnya. Lingkungan sosial ini meliputi, interaksi dengan teman sebaya, keluarga maupun orang-orang di sekitarnya. Dalam menyelesaikan tugas belajarnya, siswa tidak terlepas dari bantuan orang lain, baik dalam diskusi masalah pelajaran maupun menjadi tutor teman sebaya. Interaksi umum yang dilakukan siswa dengan lingkungan sosialnya seperti kerja kelompok dengan teman sebaya, diskusi dengan orang tua terkait tugas sekolah. Kurangnya interaksi siswa dengan lingkungan sekitarnya menyebabkan sulitnya siswa memperoleh bantuan dalam menyelesaikan permasalahan yang dijumpai pada tugas belajarnya.

Selain itu, dalam memilih mitra belajar siswa harus selektif, dengan tujuan agar siswa tidak terjerumus dengan lingkungan yang salah, dan berdampak negatif terhadap aktivitas belajarnya. Siswa kelas XI IPS pada Mata Pelajaran Ekonomi masih belum selektif dalam memilih sumber maupun mitra belajar untuk membantu mereka dalam memahami materi pelajaran maupun menyelesaikan tugas-tugas belajar. Jadi dapat dikatakan lingkungan sosial memiliki peran penting dalam mendorong tercapainya hasil belajar yang baik serta terwujudnya tujuan belajar yang telah ditetapkan. Hal ini diindikasi oleh pendapat Nugroho (2015) yang menyatakan bahwa lingkungan sosial berpengaruh positif terhadap hasil belajar siswa. Sehingga, diharapkan siswa lebih berinteraksi dengan lingkungan sosialnya, seperti mencari tutor sebaya dan lebih selktif dalam memilih sumber dan mitra belajar untuk memudahkan dalam memecahkan permasalahan belajar yang dihadapi.

\section{SIMPULAN DAN SARAN}

Berdasarkan hasil analisis data dan pembahasan yang telah dipaparkan sebelumnya, maka peneliti dapat menarik kesimpulan sebagai berikut. Self-Regulated Learning siswa kelas XI IPS pada Mata Pelajaran Ekonomi di SMA Negeri 3 Singaraja ditinjau dari dimensi motif 
p-ISSN : 2599-1418

e-ISSN : 2599-1426

memperoleh skor sebesar 2.057 yang berada pada rentang skor 1.751-2.162, sehingga dikategorikan baik. Self-Regulated Learning siswa kelas XI IPS pada Mata Pelajaran Ekonomi di SMA Negeri 3 Singaraja ditinjau dari dimensi metode memperoleh skor sebesar 2.037 yang berada pada rentang skor 1.751-2.162, sehingga dikategorikan baik. Self-Regulated Learning siswa kelas XI IPS pada Mata Pelajaran Ekonomi di SMA Negeri 3 Singaraja ditinjau dari dimensi waktu memperoleh skor sebesar 1.028 yang berada pada rentang skor 804-1.050, sehingga dikategorikan kurang baik.

Self-Regulated Learning siswa kelas XI IPS pada Mata Pelajaran Ekonomi di SMA Negeri 3 Singaraja ditinjau dari dimensi perilaku memperoleh skor sebesar 2.863 yang berada pada rentang skor 2.451-3.027, sehingga dikategorikan baik. Self-Regulated Learning siswa kelas XI IPS pada Mata Pelajaran Ekonomi di SMA Negeri 3 Singaraja ditinjau dari dimensi lingkungan fisik memperoleh skor sebesar 1.192 yang berada pada rentang skor 1.051-1.297, sehingga dikategorikan baik.

Self-Regulated Learning siswa kelas XI IPS pada Mata Pelajaran Ekonomi di SMA Negeri 3 Singaraja ditinjau dari dimensi lingkungan sosial memperoleh skor sebesar 1.734 yang berada pada rentang skor 1.3391.750, sehingga dikategorikan kurang baik. Peneliti dapat menarik kesimpulan bahwa self-regulated learning siswa kelas XI IPS pada Mata Pelajaran Ekonomi di SMA Negeri 3 Singaraja yang ditinjau dari dimensi motif, metode perilaku dan lingkungan fisik menunjukkan hasil yang baik, sedangkan ditinjau dari dimensi waktu dan lingkungan sosial menunjukkan hasil yang kurang baik.

Berdasarkan hasil, pembahasan dan simpulan yang telah dipaparkan sebelumnya, maka peneliti mengajukan saran yaitu bagi siswa kelas XI IPS di SMA Negeri 3 Singaraja disarankan untuk belajar mengatur waktu mulai sejak dini, membuat jadwal belajar, menentukan tugas yang menjadi prioritas. Selain itu, siswa disarankan menjalin hubungan baik dengan linngkungan sosial, meliputi keluarga, teman
Jurnal Pendidikan Ekonomi Undiksha

Vol. 13 No.2 (2021)

sejawat dalam memecahkan masalah pembelajaran.

Bagi peneliti selanjutnya disarankan lebih mengembangkan lagi penelitian ini, karena pada penelitian ini hanya meneliti mengenai self-regulated learning ditinjau dari dimensi motif, metode, waktu, perilaku, lingkungan fisik dan lingkungan sosial,sehingga untuk peneliti selanjutnya untuk dapat mengembangkan self-regulated learning dari konteks yang berbeda.

\section{DAFTAR PUSTAKA}

Arikunto, S. (2005). Manajemen Penelitian. PT. Rineka Cipta.

Fasikhah, S. S., \& Fatimah, S. (2013). SelfRegulated Learning (SRL) Dalam meningkatkan Prestasi Akademik Mahasiswa. Jurnal IImiah Psikologi Terapan. Jurnal IImiah Psikologi Terapan., 1, 1.

Febriyanti, F., \& Imami, A. I. (2021). Analisis Self-Regulated Learning dalam Pembelajarn Matematika Pada Siswa SMP. Jurnal IImiah Soulmath Jurnal Edukasi Pendidikan Matematika, 9, 110.

Hidayah, N., \& Atmoko, A. (2014). Landasan Sosial Budaya Dan Psikologi Pendidikan Terapannya Di Kelas. Penerbit Gunung Samudera.

Jacob, L., Benick, M., Dörrenbächer, S., \& Perels, F. (2020). Promoting SelfRegulated Learning In Preschoolers. Journal Of Childhood, Education \& Society. Journal Of Childhood, Education \& Society, 1(2), 116-140.

Koro, M., Djamika, E. T., \& Ramli, M. (2017). Self-Regulated Learning Sebagai Strategi Belajar Siswa Sekolah Dasar. Prosiding TEP \& PDs, 29, 788-795.

Kurnia, D., \& Warmi, A. (2020). Analisis SelfReglated Learning Dalam Pembelajaran Matematika Pada Siswa SMP Kelas VIII Ditinjau Dari Fase-fase Self-Regulated Learning. PROSIDING SESIOMADIKA, 2(1b).

Lestari, P. (2014). Self Monitoring. Jurnal Matematika Dan Pendidikan Matematika., 3(1). 
p-ISSN : 2599-1418

e-ISSN : 2599-1426

Mulyani, M. D. (2013). Hubungan Antara MAnajemen Waktu Dengan Self Regulated Learning Pada Mahasiswa. Educational Psychology Journal, 2(1).

Nugroho, A. D. (2015). Pengaruh Lingkungan Sosial Dan Fasilitas Sekolah Terhadap Hasil Belajar Akuntansi Pada Siswa Kelas XI dan XII IPS 1 MAN 1 Manidun TAhun Ajaran 2014/2015. Fourum IImiah Pendidikan Akuntansi, 3(2).

Puspita, S. A. L., \& Rustika, I. M. (2018). Peran Self-Regulated Learning dan Konsep Diri Terhadap Prestasi Akademik Mahasiswa Remaja Akhir Fakultas Kedokteran Universitas Udayana Yang Pernah Menjadi Finalis Bali Pageants. Jurnal Psikologi Udayana, 5(1), 1-11.

Rahmiyati, A. (2017). Pengaruh SelfRegulated Learning Terhadap Prestasi Belajar Siswa Kelas X Pada Mata Pelajaran Ekonomi. Jurnal Pendidikan Dan Pembelajaran Khatulistiwa, 6(9).

Sucipto. (2014). Pengaruh Self-Regulated Learning Dan Dukungan Orang Tua Terhadap Hasil Belajar Peserta Didik Pada Mata Pelajaran Ekonomi Program Studi IPS SMA Di Kota Jombang.
Jurnal Pendidikan Ekonomi Undiksha

Vol. 13 No.2 (2021)

Jurnal Ekonomi Pendidikan Dan Kewirausahaan, 2(2).

Sutikno. (2016). Kontribusi Self-Regulated Learning Dalam Pembelajaran. Jurnal STKIP PGRI Trenggalek, 22(2), 288203.

Winoto, S. (2020). Dasar-Dasar Manajemen Pendidikan. BILDUNG.

Yeni, M., Maizarah, \& Ridhwan, M. (2021). Self-Regulated Learning In English Classroom. ELT-Lectura: Studies And Perspectives In English Language Teaching, 8(1).

Yulanda, N. (2017). Pengaruh SelfRegulated Learning Peserta Didik Dalam Peggunaan Gedget. And Development Journal Of Education, 3(2).

Yuliastanty, S., \& Nazif, H. (2019). Pengaruh Lingkungan Keluarga, Lingkungan Fisik, Motivasi Belajar, Kedisiplinan Terhadap Hasil Belajar Mahasiswa UUniversitas Eka Sakti Padang (UNES). Jurnal Penelitian Kajian IImu Menara IImu, 13(11).

Zimmerman, B. J. (2013). Applications Of Self-Regulated Learning Across Diverse Discipline. IAP. 